\title{
First successful culture of the marine dinoflagellate Dinophysis acuminata
}

\author{
Myung Gil Park ${ }^{1, *}$, Sunju Kim², Hyung Seop Kim³ , Geumog Myung ${ }^{2}$, \\ Yi Gu Kang ${ }^{2}$, Wonho Yih $^{2}$ \\ ${ }^{1}$ Department of Oceanography, Chonnam National University, Gwangju 500-757, Republic of Korea \\ ${ }^{2}$ Department of Oceanography, Kunsan National University, Kunsan 573-701, Republic of Korea \\ ${ }^{3}$ Gunsan Regional Maritime Affairs and Fisheries Office, MOMAF, Kunsan 573-882, Republic of Korea
}

\begin{abstract}
The dinoflagellate genus Dinophysis includes several species that cause diarrhetic shellfish poisoning, none of which have yet been established in culture. We report on the maintenance of Dinophysis acuminata cultures that were established in December 2005 and also on its feeding mechanism, and growth rates when fed the ciliate prey Myrionecta rubra with and without the addition of the cryptophyte Teleaulax sp. D. acuminata grew well (growth rate of $0.95 \mathrm{~d}^{-1}$ ) in laboratory culture when supplied with the marine ciliate M. rubra as prey, reaching a maximum concentration of about 2400 cells ml ${ }^{-1}$ at the end of the feeding experiment. In contrast, $D$. acuminata did not show sustained growth in the absence of the ciliate or when provided the cryptophyte Teleaulax sp. as prey $(D$. acuminata used its peduncle to extract the cell contents of the prey organism, M. rubra). Based on the prey- predator interactions occurring among $D$. acuminata, $M$. rubra, and Teleaulax sp. in this study, establishment of permanent culture of the dinoflagellate $D$. acuminata may facilitate a better understanding of the ecophysiology, biology, and toxicology of Dinophysis species, as well as the evolution of dinoflagellate plastids.
\end{abstract}

KEY WORDS: Dinophysis acuminata · Cultivation · Myrionecta rubra $\cdot$ Diarrhetic shellfish poisoning $\cdot$ Feeding

Resale or republication not permitted without written consent of the publisher

\section{INTRODUCTION}

The marine dinoflagellate genus Dinophysis includes both phototrophic and heterotrophic species and is globally distributed in coastal and oceanic waters (Hallegraeff \& Lucas 1988, Hallegraeff 1993).

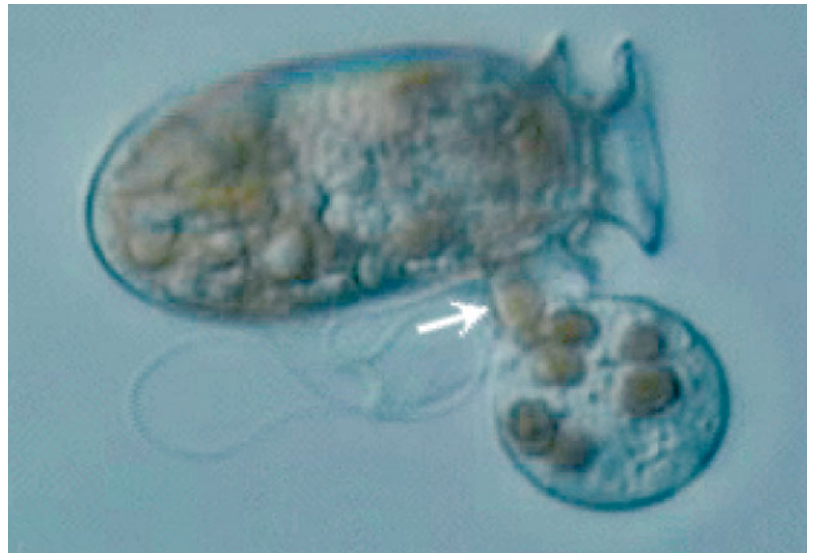

Dinophysis acuminata feeding on the marine ciliate Myrionecta rubra by extracting its cytoplasm through a peduncle. Photo: Myung Gil Park

Cell abundances of Dinophysis species are usually low

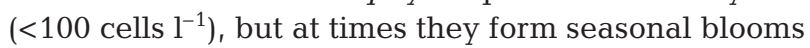
with a few thousand cells per liter in some areas of Europe and Japan (Dahl et al. 1996, Nishitani et al. 2005). Dinophysis species are of economic and public importance as they cause diarrhetic shellfish poisoning and have a significant effect on shellfish industries in many parts of the world (Boni et al. 1993, Dahl et al. 1996, Giacobbe et al. 2000) because of the threat to human health after consumption of contaminated shellfish (Hallegraeff 1993). Nonetheless, further detailed exploration of the ecophysiology, biology, and toxicology of the Dinophysis species has been hampered by an inability to culture them. Therefore, our current knowledge about Dinophysis species has been derived only from natural populations. 
Photosynthetic species of Dinophysis do not survive when cultured in various media that support growth of many other phytoplankton species (Sampayo 1993, Maestrini et al. 1995). Microscopic observations (Jacobson \& Andersen 1994, Nishitani et al. 2002) show that photosynthetic species often contain food vacuoles, reflecting mixotrophy, indicating that feeding may be necessary for successful culture of Dinophysis species. However, despite the supply of potential prey organisms, including cryptophytes (Nishitani et al. 2003), all attempts to cultivate members of the genus Dinophysis have failed. While ultrastructural and molecular studies and pigment analyses all demonstrate that photosynthetic Dinophysis species contain plastids of cryptophyte origin (Schnepf \& Elbrächter 1988, Lucas \& Vesk 1990, Hewes et al. 1998, Takishita et al. 2002, Hackett et al. 2003, Janson \& Granéli 2003, Janson 2004), the way in which they enter Dinophysis cells has not yet been confirmed. In the present study, we report on the establishment of Dinophysis acuminata in culture, its feeding mechanism, and its growth rate using the ciliate prey Myrionecta rubra with and without the addition of the cryptophyte Teleaulax sp.

\section{MATERIALS AND METHODS}

Cultures. Dinophysis acuminata was established in culture by isolating single cells from seawater samples collected in Masan Bay, Korea $\left(128^{\circ} 34^{\prime} \mathrm{E}, 35^{\circ} 12^{\prime} \mathrm{N}\right)$ on 20 December 2005. The Dinophysis culture was grown in $30 \mathrm{psu}$ f/2-Si medium at $20^{\circ} \mathrm{C}$ under continuous light (60 $\mu \mathrm{mol}$ photons $\mathrm{m}^{-2} \mathrm{~s}^{-1}$ ) with addition of the marine ciliate Myrionecta rubra as the prey species every 2 to $3 \mathrm{~d}$. Cultures of $M$. rubra (strain MR-MAL01) were grown using the cryptophyte Teleaulax sp. (strain CR-MAL01) as prey, as described in detail by Yih et al. (2004). The cryptophyte culture was grown under the same conditions described above. All of the 3 cultures were non-axenic.

Feeding experiments. A dense culture of Dinophysis acuminata in exponential growth was split into 3 aliquots and diluted with fresh medium to prepare triplicate $300 \mathrm{ml}$ bottles for each of 3 experimental treatments. Treatment bottles received either Myrionecta rubra, the cryptophyte Teleaulax sp., or a mixture of $M$. rubra and Teleaulax sp. as prey for D. acuminata. For controls, triplicate bottles were established for $D$. acuminata without prey, $M$. rubra alone, Teleaulax sp. alone, and a mixture of M. rubra and Teleaulax sp. Initial concentrations of D. acuminata, M. rubra, and Teleaulax sp. in experimental and control bottles were 100,500, and 500 cells ml$^{-1}$, respectively. All treatments and controls were incubated at $20^{\circ} \mathrm{C}$ under continuous light $(60 \mu \mathrm{mol}$ photons $\mathrm{m}^{-2} \mathrm{~s}^{-1}$ ) for $7 \mathrm{~d}$. Daily subsamples were fixed with acid Lugol's solution and cells were enumerated using a Sedgewick-Rafter chamber.

Microscopy. Live observations of the feeding process were made on a glass slide using an Olympus BX51 microscope at 400× magnification and recorded with a Sony Progressive 3CCD colour video camera attached to a digital imaging time-lapse recorder. Video sequences were frame grabbed and individual frames were exported in JPEG format. For observations of plastid density and autofluorescence in Dinophysis cells, light and epifluorescence micrographs of live cells were taken at $1000 \times$ magnification using a digital camera (PowerShot G5, Canon) coupled to the Olympus BX51 microscope equipped with differential interference contrast and fluorescence cube (UMWB2, 450-480 nm excitation, $500 \mathrm{~nm}$ emission).

\section{RESULTS AND DISCUSSION}

\section{Cultivation of Dinophysis acuminata}

When grown in $30 \mathrm{psu} \mathrm{f} / 2-\mathrm{Si}$ medium at $20^{\circ} \mathrm{C}$ in continuous light $\left(60 \mu \mathrm{mol}\right.$ photons $\left.\mathrm{m}^{-2} \mathrm{~s}^{-1}\right)$ and supplied with the marine ciliate Myrionecta rubra as prey, Dinophysis acuminata reached densities greater than $1.1 \times$ $10^{4}$ cells $\mathrm{ml}^{-1}$. No sustained growth was observed in the absence of the ciliate prey.

\section{Growth and feeding of Dinophysis acuminata}

Dinophysis acuminata grew well when offered Myrionecta rubra as prey (Fig. 1a), with cell numbers remaining constant during the first day and increasing exponentially at a growth rate of $0.95 \mathrm{~d}^{-1}$ (doubling time $17.5 \mathrm{~h}$ ) over the next $3 \mathrm{~d}$. After $4 \mathrm{~d}$, initial M. rubra cells had declined by $97.5 \%$, yet $D$. acuminata slowly continued to increase in numbers, reaching a maximum concentration of about 2400 cells ml $^{-1}$ at the end of the experiment. In control bottles without the predators, M. rubra cell numbers increased exponentially with a growth rate of $0.61 \mathrm{~d}^{-1}$ by Day 5, and remained constant thereafter (Fig. 1b). When cryptophytes were offered as prey, D. acuminata cell numbers increased slightly to about 280 cells ml $\mathrm{m}^{-1}$ (growth rate $0.31 \mathrm{~d}^{-1}$ ) over the first $4 \mathrm{~d}$ and thereafter declined rapidly until the end of the experiment (Fig. 1c). The slight initial increase in $D$. acuminata cell numbers in the presence of Teleaulax sp. did not appear to reflect growth supported by predation or kleptoplastidy, or both, on cryptophyte cells since growth of $D$. acuminata occurred at a similar rate $\left(0.32 \mathrm{~d}^{-1}\right)$ in control cultures without prey (Fig. 1e). When grown with both $M$. rubra and Teleaulax sp., D. acuminata cell numbers increased to about 2500 cells 
$\mathrm{ml}^{-1}$ over the first $4 \mathrm{~d}$ (growth rate of $0.91 \mathrm{~d}^{-1}$ ), subsequently decreased slowly for $2 \mathrm{~d}$, and then sharply declined to near zero values by the end of the experiment (Fig. 1f). The sharp decline in D. acuminata after $6 \mathrm{~d}$ was accompanied by a parallel decline in $M$. rubra prey. The lack of ciliates, however, seems not to have been the primary cause for the decline in $D$. acuminata as this dinoflagellate is capable of surviving for many days in the absence of prey (Fig. 1e). A similar decline in $D$. acuminata was observed in bottles containing crypto-
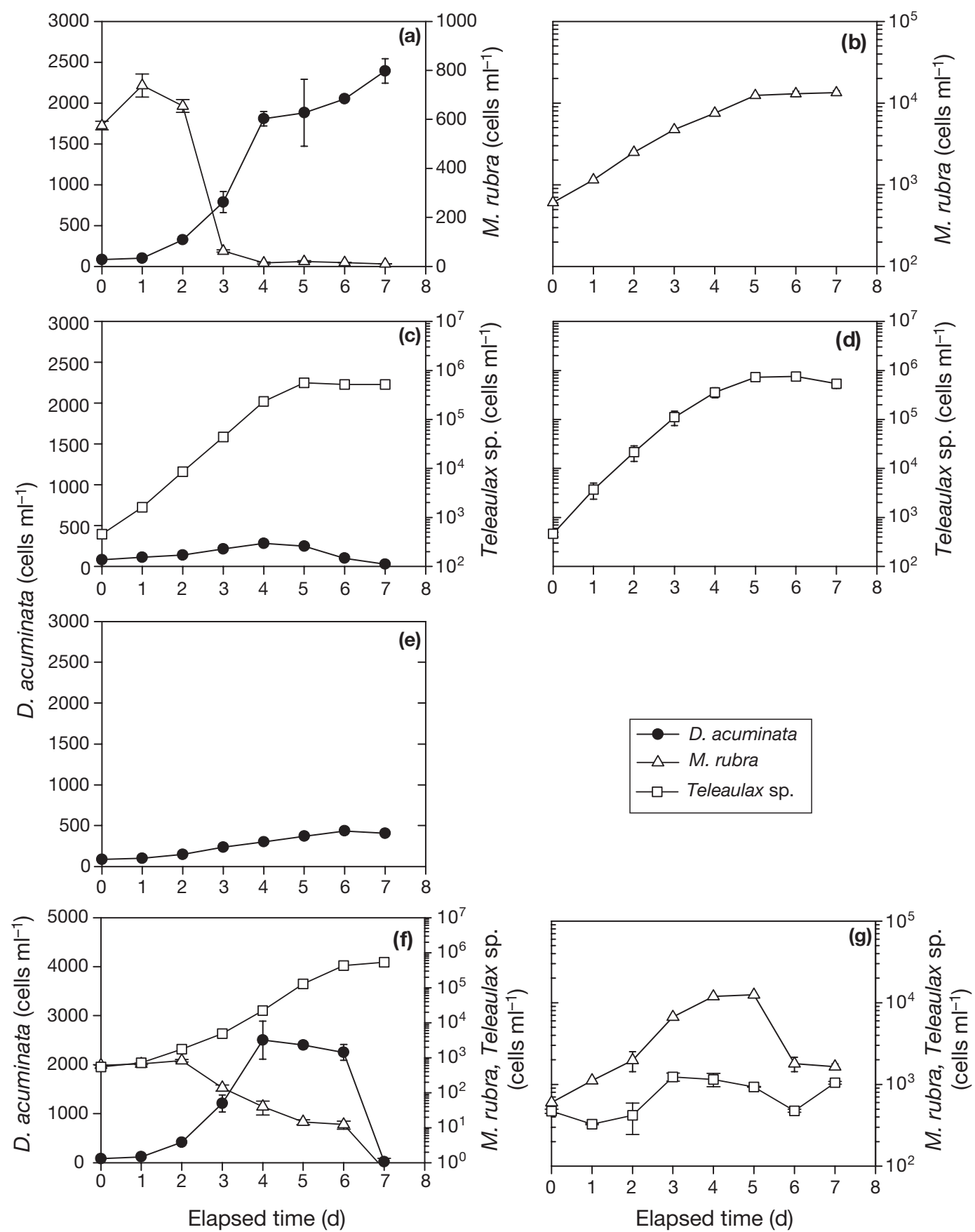

Fig. 1. Dinophysis acuminata. Characteristics of batch culture growth. (a) Changes in cell numbers of $D$. acuminata and Myrionecta rubra in cultures supplied with the ciliate M. rubra as prey. (b) Growth of M. rubra in cultures without the predator D. acuminata. (c) Changes in cell numbers of D. acuminata and Teleaulax sp. in cultures with the cryptophyte Teleaulax sp. provided as prey. (d) With only cryptophytes. (e) With only D. acuminata. (f) Growth of D. acuminata in cultures with a mixture of ciliate and cryptophytes provided as prey. (g) Growth of ciliate and cryptophytes in cultures without predator. Data were shown as meanvalues $( \pm 1 \mathrm{SE})$ of 3 replicate cultures 
phytes as potential prey (Fig. 1C, f), which suggests that inhibition of $D$. acuminata growth was due to nutrient competition or allelopathy from Teleaulax sp. Another plausible explanation for the sharp decline in D. acuminata could be that the 3 species may differ in their $\mathrm{pH}$ limits for growth (Hansen 2002, Pedersen \& Hansen 2003, Hansen \& Fenchel 2006). The cryptophyte Teleaulax sp. may have a higher $\mathrm{pH}$ limit for growth compared with M. rubra (Hansen \& Fenchel 2006) or D. acuminata and, thus, these 2 species may reach their $\mathrm{pH}$ limits for growth before Teleaulax sp.

\section{Feeding process of Dinophysis acuminata}

Microscopic observations of live cells using our established cultures revealed that Dinophysis acuminata uses a peduncle to extract the cell contents of the ciliate Myrionecta rubra (Fig. 2). While peduncle feeding has been reported for the heterotrophic species D. rotundata and D. hastata (Hansen 1991), the feeding mechanism used by photosynthetic or mixotrophic species of Dinophysis has not been previously observed. However, ultrastructure
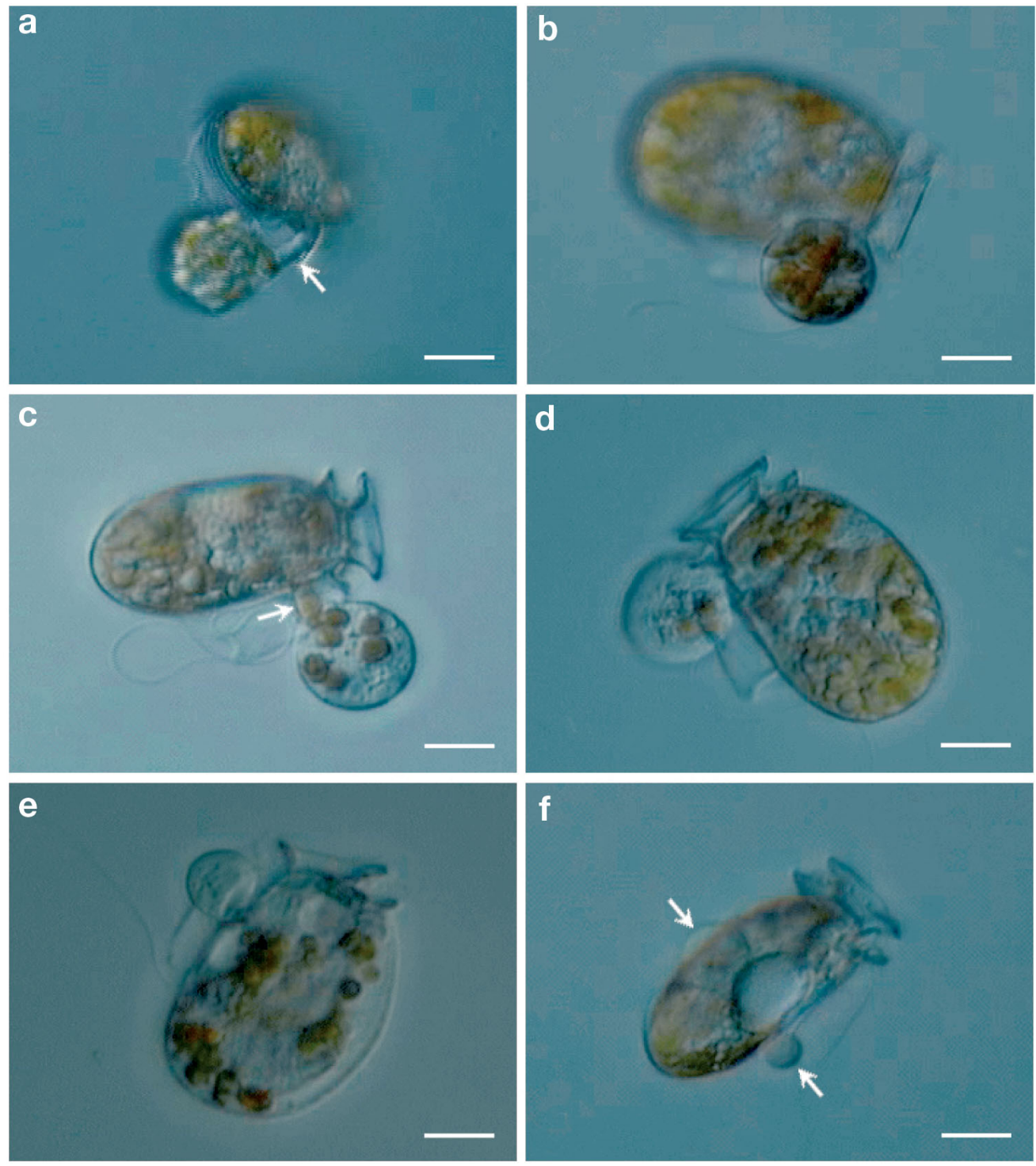

Fig. 2. Dinophysis acuminata. Light micrographs of live cells feeding on the ciliate Myrionecta rubra. (a) Peduncle (arrow) of the dinoflagellate $D$. acuminata during swimming with a captured $M$. rubra cell suspended. (b) D. acuminata with a recently captured $M$. rubra prey organism. Note that all cilia of the ciliate were detached from the body. (c) D. acuminata feeding on M. rubra by extracting its cytoplasm through a peduncle. The ciliate prey has only 6 chloroplasts left and 1 chloroplast is passing through the peduncle (arrow) into the dinoflagellate. $(\mathrm{d}, \mathrm{e}) \mathrm{D}$. acuminata that has acquired most of the chloroplasts of the prey. (f) $D$. acuminata with balloon-like spheres (arrows) near its surface after feeding. Scale bars $=10 \mu \mathrm{m}$. Video available as supplementary material at: www.int-res.com/articles/suppl/a045p101_video 
has revealed the presence of microtubular ribbons inside D. acuminata and D. norvegica (Jaconson \& Andersen 1994) that are presumably used during feeding. The precapture behaviour of $D$. acuminata differs from that of other marine thecate dinoflagellates (i.e. searching type) (Jacobson \& Anderson 1986, Hansen \& Calado 1999) but is similar to that of the heterotrophic dinoflagellates $D$. rotundata and $D$. hastata (i.e. trapping type) (Hansen 1991, Hansen \& Calado 1999). The ciliate $M$. rubra, which has pronounced jumping behaviour, is captured by the dinoglagellate upon mechanical contact. After making physical contact, D. acuminata pierces $M$. rubra with a peduncle. Once trapped, the ciliate temporarily swims for about $1 \mathrm{~min}$, towing the attached $D$. acuminata. However, the ciliate soon becomes immobile and the dinoflagellate then swims freely around towing the attached ciliate. At this time, D. acuminata starts to gradually consume the ciliate. During the early stage of feeding (i.e. capturing of prey and swimming), most cilia are shed from the body of M. rubra (Fig. 2a,b). During feeding, D. acuminata extracts the contents of the prey using the peduncle that extends from the flagellar pore. During the last stage of the feeding process, which lasts for about 1 to $2 \mathrm{~h}$, the $D$. acuminata cell is filled with vacuoles containing ciliate cytoplasm (Fig. 2d,e). In addition, plastids were frequently noticed within the cytoplasm of D. acuminata (Fig. 3a,b). Epifluorescence microscopy revealed that $D$. acuminata emitted bright yellow-orange fluorescence under blue light excitation (Fig. 3c), typical of cryptophycean phycobilin (phycoerythrin). After the feeding event, D. acuminata was frequently observed with balloonlike spheres of varying size distributed close to the cell surface (Fig. 2f).

\section{Establishment of Dinophysis acuminata in culture and its implications}

To our knowledge, this is the first report on extended cultivation of a species belonging to the genus Dinophysis. Despite considerable effort since the early work of Barker approximately 70 yr ago (Barker 1935), all attempts to cultivate Dinophysis species have failed. This has posed a major obstacle to detailed study of the ecophysiology, life history, toxicology, and evolution of the plastids in members of this genus. Dinoflagellates possess 5 different types of plastids and have acquired and lost them many times during their evolution (Schnepf \& Elbrächter 1999). While Dinophysis species are now known to possess cryptophyte-type plastids, the route by which the plastid enters Dinophysis cells remains unknown.

Like Dinophysis acuminata, the planktonic ciliate Myrionecta rubra contains plastids of cryptophyte origin. The origin of the plastids has been proposed to be via kleptoplastidy following ingestion of the cryptophyte (Gustafson et al. 2000, Yih et al. 2004). Recently, however, Hansen \& Fenchel (2006) have argued that the plastids of $M$. rubra are not kleptoplastids. They postulated, using morphological and experimental evidence, that $M$. rubra does not acquire chloroplasts from its cryptophyte prey; rather it feeds on cryptophytes in order to gain an essential growth factor for continuous growth. Similarly, D. acuminata may get its plastids as kleptoplastidy from ingesting $M$. rubra. If so, the plastids would be secondary kleptoplastids if Gustafson et al. (2000) and Yih et al. (2004) are correct about the origin of $M$. rubra plastids. If, however, Hansen \& Fenchel (2006) are correct, then the plastids of $D$. acuminata would be primary kleptoplastids. Alternatively, D. acuminata may have its own plastids
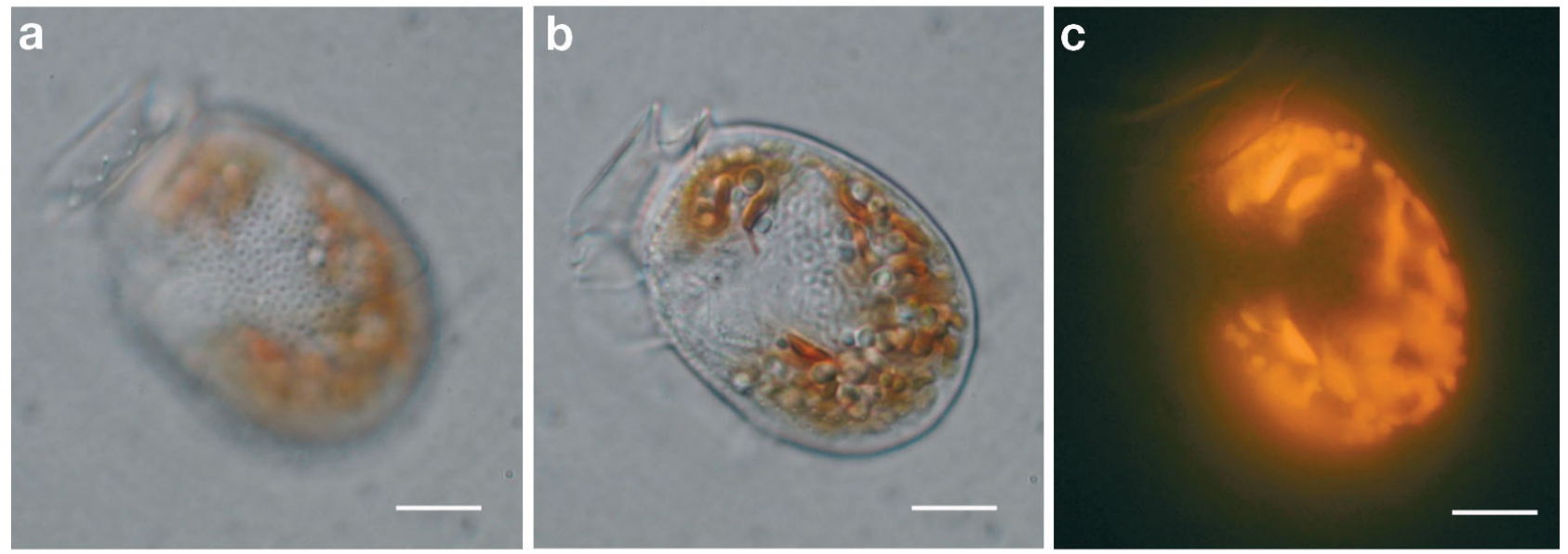

Fig. 3. Dinophysis acuminata. Typical light and epifluorescence micrographs of well fed cells using the ciliate prey Myrionecta rubra: (a) surface focus; (b) central focus; (c) epifluorescence of the same cell. Scale bars $=10 \mu \mathrm{m}$ 
and simply eat $M$. rubra to acquire some essential growth factor, as Hansen \& Fenchel (2006) argued for M. rubra.

The establishment of Dinophysis acuminata cultures promises to improve our knowledge of the evolution of the dinoflagellate plastids and the more complicated interactions among the 3 organisms $D$. acuminata, $M$. rubra and Teleaulax sp. within marine planktonic food webs. Cultivation of Dinophysis in this study solves a major bottleneck in this research and our findings will allow other laboratories around the world to expand research efforts on this cosmopolitan species.

Acknowledgements. We thank Dr. D. Wayne Coats (Smithsonian Environmental Research Center) for invaluable comments on the manuscript and for an in-depth discussion on the manuscript during the 12th International Conference on Harmful Algae in Copenhagen, Denmark. Thanks also to Dr. P. J. Hansen and 2 anonymous reviewers for their comments and suggestions on an early version of the manuscript. This work was supported by the 2005 Korea Sea Grant Program to M.G.P. and a KOSEF grant (Red Tide National Research Laboratory, Kunsan National University, Korea) to W.Y.

\section{LITERATURE CITED}

Barker HA (1935) The culture and physiology of the marine dinoflagellates. Arch Microbiol 6:157-181

Boni L, Milandri A, Poletti R, Pompei M (1993) DSP cases along the coasts of Emilia-Romagna (Northwest Adriatic Sea). In: Smayda TJ, Shimizu Y (eds) Toxic phytoplankton blooms in the sea. Elsevier, Amsterdam, p 475-481

Dahl E, Aune T, Aase B (1996) Reddish water due to mass occurrence of Dinophysis spp. 1996. In: Yasumoto T, Oshima Y, Fukuyo Y (eds) Harmful and toxic algal blooms. Intergovernmental Oceanographic Commission of UNESCO, p 265-267

Giacobbe MG, Penna A, Ceredi A, Milandri A, Poletti R, Yang X (2000) Toxicity and ribosomal DNA of the dinoflagellate Dinophysis sacculus (Dinophyta). Phycologia 39:177-182

Gustafson DE, Stoecker DK, Johnson MD, Van Heukelem WF, Snaider K (2000) Cryptophyte algae are robbed of their organelles by the marine ciliate Mesodinium rubrum. Nature 405:1049-1052

Hackett JD, Maranda L, Yoon HS, Bhattacharya D (2003) Phylogenetic evidence for the cryptophyte origin of the plastid of Dinophysis (Dinophysiales, Dinophyceae). J Phycol 39:440-448

Hallegraeff GM (1993) A review of harmful algal blooms and their apparent global increase. Phycologia 32:79-99

Hallegraeff GM, Lucas IAN (1988) The marine dinoflagellate genus Dinophysis (Dinophyceae): photosynthetic, neritic and non-photosynthetic, oceanic species. Phycologia 27: 25-42

Hansen PJ (1991) Dinophysis - a planktonic dinoflagellate genus which can act both as prey and predator. Mar Ecol Prog Ser 69:201-204

Hansen PJ (2002) Effect of high pH on the growth and survival of marine phytoplankton: implications for species succession. Aquat Microb Ecol 28:279-288

Hansen PJ, Calado AJ (1999) Phagotrophic mechanisms and prey selection in free-living dinoflagellates. J Eukaryot Microbiol 46:382-389

Hansen PJ, Fenchel T (2006) The bloom-forming ciliate Mesodinium rubrum harbours a single permanent endosymbiont. Mar Biol Res 2:169-177

Hewes CD, Mitchell BG, Moisan TA, Vernet M, Reid FMH (1998) The phycobilin signatures of chloroplasts from three dinoflagellate species: a microanalytical study of Dinophysis caudata, D. fortii, and D. acuminata (Dinophysiales, Dinophyceae). J Phycol 34:945-951

Jacobson DM, Andersen RA (1994) The discovery of mixotrophy in photosynthetic species of Dinophysis (Dinophyceae): light and electron microscopical observations of food vacuoles in Dinophysis acuminata, $D$. norvegica and two heterotrophic dinophysoid dinoflagellates. Phycologia 33:97-110

Jacobson DM, Anderson DM (1986) Thecate heterotrophic dinoflagellates: feeding behaviour and mechanism. J Phycol 22:249-258

Janson S (2004) Molecular evidence that plastids in the toxinproducing dinoflagellate genus Dinophysis originate from the free-living cryptophyte Teleaulax amphioxeia. Environ Microbiol 6:1102-1106

Janson S, Granéli E (2003) Genetic analysis of the psbA gene from single cells indicates a cryptomonad origin of the plastid in Dinophysis (Dinophyceae). Phycologia 42: 473-477

Lucas IAN, Vesk M (1990) The fine structure of two photosynthetic species of Dinophysis (Dinophysiales, Dinophyceae). J Phycol 26:345-357

Maestrini SY, Berland BR, Grzebyk D, Spano AM (1995) Dinophysis spp. cells concentrated from nature for experimental purposes, using size fractionation and reverse migration. Aquat Microb Ecol 9:177-182

Nishitani G, Sugioka H, Imai I (2002) Seasonal distribution of species of the toxic dinoflagellate genus Dinophysis in Maizuru Bay (Japan), with comments on their autofluorescence and attachment of picophytoplankton. Harmful Algae 1:252-264

Nishitani G, Miyamura K, Imai I (2003) Trying to cultivation of Dinophysis caudata (Dinophyceae) and the appearance of small cells. Plankton Biol Ecol 50:31-36

Nishitani G, Yamaguchi M, Ishikawa A, Yanagiya S, Mitsuya T, Imai I (2005) Relationships between occurrences of toxic Dinophysis species (Dinophyceae) and small phytoplankton in Japanese coastal waters. Harmful Algae 4:755-762

Pedersen MF, Hansen PJ (2003) Effects of high pH on the growth and survival of six marine heterotrophic protests. Mar Ecol Prog Ser 260:33-41

Sampayo MAdeM (1993) Trying to cultivate Dinophysis spp. In: Smayda TJ, Shimizu Y (eds) Toxic phytoplankton blooms in the sea. Elsevier, Amsterdam, p 807-810

Schnepf E, Elbrächter M (1988) Cryptophycean-like double membrane-bound chloroplast in the dinoflagellate, Dinophysis Ehrenb.: evolutionary, phylogenetic and toxicological implications. Bot Acta 101:196-203

Schnepf E, Elbrächter M (1999) Dinophyte chloroplasts and phylogeny - a review. Grana 38:81-97

Takishita K, Koike K, Maruyama T, Ogata T (2002) Molecular evidence for plastid robbery (kleptoplastidy) in Dinophysis, a dinoflagellate causing diarrhetic shellfish poisoning. Protist 153:293-302

Yih W, Kim HS, Jeong HJ, Myung G, Kim YG (2004) Ingestion of cryptophyte cells by the marine photosynthetic ciliate Mesodinium rubrum. Aquat Microb Ecol 36:165-170 